\title{
Effects of astragaloside IV on inflammation and immunity in rats with experimental periodontitis
}

\author{
Liqiong ZHANG (a) iD \\ Shaolin DENG(a) iD \\ (a) Huazhong University of Science and \\ Technology, Tongii Medical College, \\ The Central Hospital of Wuhan, Wuhan \\ 430014, China.
}

Declaration of Interests: The authors certify that they have no commercial or associative interest that represents a conflict of interest in connection with the manuscript.

\section{Corresponding Author:}

Shaolin Deng

E-mail: dengshaolinwh@163.com

https://doi.org/10.1590/1807-3107bor-2019.vol33.0032

Submitted: October 25, 2018

Accepted for publication: February 26, 2019

Last revision: March 19, 2019

\begin{abstract}
This study aimed to investigate the effects of astragaloside IV (AsIV) on inflammation and immunity in rats with experimental periodontitis. Periodontitis was established in 48 Wistar rats, which were then randomly divided into model and 10, 20 and $40 \mathrm{mg} / \mathrm{kg}$ AsIV groups, with 12 rats in each group. The latter 3 groups were treated with AsIV at doses of 10, 20 and $40 \mathrm{mg} / \mathrm{kg}$, respectively. The control group (12 rats, without periodontitis) and model group were given the same amount of $5 \%$ sodium carboxymethyl cellulose. The treatment was performed once per day for 8 weeks. Before and after treatment, the tooth mobility scores of the rats were determined. After treatment, the salivary occult blood index (SOBI), plaque index (PLI), peripheral blood $\mathrm{T}$ lymphocyte subsets, and serum inflammatory factor and immunoglobulin levels were determined. The results showed that, after treatment, compared with that in model group, in $40 \mathrm{mg} / \mathrm{kg}$ AsIV group, the general state of rats was improved, while the tooth mobility score, SOBI and PLI were significantly decreased $(\mathrm{p}<0.05)$; the peripheral blood $\mathrm{CD}_{4}{ }^{+} \mathrm{T}$ cell percentage and $\mathrm{CD}_{4}{ }^{+} / \mathrm{CD}_{8}{ }^{+}$ratio were significantly increased $(\mathrm{p}<0.05)$, while the $\mathrm{CD}_{8}^{+} \mathrm{T}$ cell percentage was significantly decreased $(p<0.05)$; the serum tumor necrosis factor- $\alpha$, interleukin-1 $\beta$ and interleukin-2 levels were significantly decreased $(\mathrm{p}<0.05)$; the serum immunoglobulin A and immunoglobulin $\mathrm{G}$ levels were significantly decreased $(p<0.05)$. In conclusion, AsIV can alleviate inflammation and enhance immunity in rats with experimental periodontitis.
\end{abstract}

Keywords: Periodontitis; Inflammation; Immunity.

\section{Introduction}

Periodontitis is a chronic and destructive disease that invades the gingiva and periodontal support tissues. It is one of the major oral diseases and has a high prevalence. The main characteristics of periodontitis are periodontal pocket formation, pocket wall inflammation, alveolar bone resorption and tooth loosening. ${ }^{1}$ Periodontitis is one of the main causes of tooth loss in adults, and it can cause or induce a variety of diseases, seriously endangering human health. It has been recognized that bacteria and their products in the periodontal tissues and gingival crevicular fluid are important factors in the pathogenesis of periodontitis. ${ }^{2}$ 
The inflammatory factors tumor necrosis factor- $\alpha$ (TNF- $\alpha$ ), interleukin-1 $\beta$ (IL-1 $\beta$ ) and interleukin-2 (IL-2) play important roles in the occurrence and development of periodontitis. ${ }^{3,4}$ The key to the successful prevention and treatment of periodontitis is controlling the bacteria and their products in the periodontal tissues and gingival crevicular fluid to maintain the microecological balance of the local periodontal environment. ${ }^{5}$ The mechanical removal of plaque is usually applied to treat periodontitis, but this approach will cause some mechanical damage to the tooth surface. ${ }^{6}$ In addition, antibiotic therapy is often used to treat periodontitis, but it is easy to cause drug resistance, toxic effects, bacterial imbalance and other side effects. ${ }^{7}$ Astragaloside IV (AsIV) is one of the active ingredients in the medical plant Astragalus membranaceus, and it is also the quality index for the content determination of Astragalus membranaceus. According to the literature, AsIV has pharmacological activities that include immunity enhancing, ${ }^{8}$ anti-inflammatory, ${ }^{9}$ antiviral, ${ }^{10}$ antiapoptotic, ${ }^{11}$ antihypertensive effects ${ }^{12}$ among other aspects. To date, there has have been no reports on the effect of AsIV on periodontitis. Thus, the purpose of this study was to investigate the effects of AsIV on inflammation and immunity in rats with experimental periodontitis.

\section{Methodology}

\section{Animals}

This study used Wistar rats (7 weeks of age; $222 \pm 10 \mathrm{~g}$; half male and half female) at the beginning of the study. The rats were acclimatized for 10 days before the experiment, and they were kept in temperature-controlled cages that were exposed to a 24-h light-dark cycle with equal light and dark time. The experimental procedure was approved by the Institutional Animal Care and Use Committee of Tongji Medical College, Huazhong University of Science and Technology.

\section{Construction of a periodontitis model}

A periodontitis model was constructed in rats. The rats were anaesthetized with $0.3 \%$ pentobarbital sodium at a dose of $10 \mathrm{ml} / \mathrm{kg}$ via intraperitoneal injection a. The gingiva was peeled open using a tooth probe, and then the maxillary first molar was ligated using $0.2 \mathrm{~mm}$-diameter stainless steel wire with knotting at the palatal side. Then, the rats were fed daily with soft feed and high-sugar water $(200 \mathrm{~g} / \mathrm{L})$. The rats in the control group only received the abdominal anesthesia and were fed normal feed and water. The feeding of the rats was continued for 4 weeks. The periodontitis model was confirmed to be successfully established in 48 rats by digital X-ray imaging and pathological section observation.

\section{Treatment of rats}

Forty-eight model rats were fed normally for 2 weeks and then divided into a model group and 10, 20 and $40 \mathrm{mg} / \mathrm{kg}$ AsIV groups, with 12 rats in each group. The ligature wire in these rats was untied. The rats in the 10, 20 and $40 \mathrm{mg} / \mathrm{kg}$ AsIV groups were intragastrically administered AsIV (HPLC purity $\geq 98 \%$; Chengdu Mansite Biotechnology Co., Ltd., Chengdu, China); the suspension was prepared using $5 \%$ sodium carboxymethyl cellulose), and the doses were 10, 20 and $40 \mathrm{mg} / \mathrm{kg}$, respectively. The rats in the control group (12 rats) and the model group were intragastrically administered the same amount of 5\% sodium carboxymethyl cellulose. The administration was conducted once per day for 8 weeks.

\section{Determination of tooth mobility}

According to the reported method, ${ }^{13}$ before and after treatment, rat tooth mobility was scored as follows: 1 point, only buccal-lingual loosening; 2 points, both buccal-lingual and mesiodistal loosening; and 3 points, buccal-lingua, mesiodistal and vertical loosening.

\section{Detection of the salivary occult blood index and plaque index}

After treatment, the salivary occult blood index (SOBI) was detected using saliva test paper. The detection results are presented as scores (1-3 points). A higher score indicated a higher SOBI. The experimental procedures were performed in accordance with the instructions of the manufacturer. The plaque index (PLI) was detected using the 
erythrosine method..$^{14}$ The detection results are presented as scores (1-5 points). A higher score indicated a higher PLI.

\section{Determination of peripheral blood T lymphocyte subsets}

After treatment, rats were anesthetized using 5\% chloral hydrate. Five milliliters of venous blood was taken by the retro-orbital puncturingthe . Some of the blood was used to prepare serum. The rest of the blood was used to assess T lymphocyte subsets using flow cytometry. ${ }^{15}$ The experimental procedures were performed in accordance with the instructions of the manufacturer (Becton, Dickinson and Company, NJ, USA).

\section{Determination of serum inflammatory factor and immunoglobulin levels}

The venous blood of rats was centrifuged at $1000 \mathrm{r} / \mathrm{min}$ for $15 \mathrm{~min}$, and the supernatant was obtained. The serum levels of inflammatory factors, including TNF- $\alpha$, IL-1 $\beta$ and IL-2, and immunoglobulins, including immunoglobulin $\mathrm{A}$ (IgA), immunoglobulin G (IgG) and immunoglobulin $\mathrm{M}(\operatorname{Ig} \mathrm{M})$, were determined using enzyme-linked immunosorbent assays. The process was performed according to the instructions of the kits (SigmaAldrich Corp., MO, USA).

\section{Statistical analysis}

SPSS 18.0 software (SPSS Inc., Chicago, IL, USA) was used for statistical analysis. The data are presented as the mean $\pm S D$. The differences among different groups were analyzed using one-way analysis of variance with the q test. $p<0.05$ indicated a statistically significant difference.

\section{Results}

\section{General state of the rats after treatment}

During the treatment period, no rats died in any of the groups. After treatment, the rats in the control group had bright and clean fur and normal activity levels, with no obvious differences compared with the same parameters before treatment. In the model group, the rats exhibited rough and less glossy fur to different degrees and decreased activity. Compared with that in the model group, the state in the other three groups was improved, especially in the $40 \mathrm{mg} / \mathrm{kg}$ AsIV group, as the state of rats in that group was close to that of the rats in the control group.

\section{Tooth mobility scores before and after treatment}

Before treatment, the tooth mobility scores were not significantly different among the model and 10, 20 and $40 \mathrm{mg} / \mathrm{kg}$ AsIV groups ( $\mathrm{p}>0.05$ ). After treatment, the tooth mobility scores in the 20 and $40 \mathrm{mg} / \mathrm{kg}$ AsIV groups were significantly lower than the corresponding scores before treatment $(\mathrm{p}<0.05)$. In addition, after treatment, the tooth mobility scores in the 20 and $40 \mathrm{mg} / \mathrm{kg}$ AsIV groups were significantly lower than those in the model and $10 \mathrm{mg} / \mathrm{kg}$ AsIV groups $(\mathrm{p}<0.05)$ (Table 1$)$.

\section{SOBI and PLI after treatment}

After treatment, the SOBI and PLI in the model group were significantly higher than those of the control group ( $\mathrm{p}<0.05)$. In the $40 \mathrm{mg} / \mathrm{kg}$ AsIV group, the SOBI and PLI were significantly lower than those in the model group and the 20 and $40 \mathrm{mg} / \mathrm{kg}$ AsIV groups $(\mathrm{p}<0.05)$ (Table 2$)$.

Table 1. Tooth mobility scores in different groups before and after treatment.

\begin{tabular}{lcc}
\hline Group & Before treatment (points) & After treatment (points) \\
\hline Model & $2.83 \pm 0.32$ & $2.79 \pm 0.38$ \\
Low-dose AsIV & $2.81 \pm 0.39$ & $2.76 \pm 0.33$ \\
Middle-dose AsIV & $2.78 \pm 0.35$ & $1.77 \pm 0.51^{* * *, * * *}$ \\
High-dose AsIV & $2.77 \pm 0.41$ & $1.71 \pm 0.33^{*, * * \cdots}$ \\
\hline$p<0.05$ compared with model group; ${ }^{* *} p<0.05$ compared with low-dose AsIV group; and ${ }^{* * *} p<0.05$ compared with before treatment. AsIV, \\
astragaloside IV.
\end{tabular}




\section{Peripheral blood T lymphocyte subsets after treatment}

After treatment, the peripheral blood $\mathrm{CD}_{4}{ }^{+}$and $\mathrm{CD}_{8}{ }^{+} \mathrm{T}$ cell percentages and their ratios in the control group were $37.56 \pm 8.46 \%, 11.56 \pm 3.56 \%$ and $3.25 \pm 0.55$, respectively, and those in the model group were $32.26 \pm 6.43 \%, 15.26 \pm 4.33 \%$ and $2.11 \pm 0.43$, respectively; significant differences were observed for each index between the two groups $(\mathrm{p}<0.05)$. The $\mathrm{CD}_{4}{ }^{+} \mathrm{T}$ cell percentage and $\mathrm{CD}_{4}^{+} / \mathrm{CD}_{8}{ }^{+}$ratio in the $40 \mathrm{mg} / \mathrm{kg}$ AsIV group were $37.26 \pm 5.66 \%$ and $3.04 \pm 0.58$, respectively, and these values were significantly higher than those in the model group $(\mathrm{p}<0.05)$. The $\mathrm{CD}_{8}{ }^{+} \mathrm{T}$ cell percentage in the $40 \mathrm{mg} / \mathrm{kg}$ AsIV group was $12.26 \pm 2.71 \%$, which was significantly lower than that in the model group $(\mathrm{p}<0.05)$ (Figure 1).

\section{Serum TNF- $\alpha$, IL-1 $\beta$ and IL-2 levels after treatment}

After treatment, the serum TNF- $\alpha$, IL-1 $\beta$ and IL-2 levels in the model group were $4.68 \pm 0.92$, $299.33 \pm 79.52$ and $23.33 \pm 8.84 \mathrm{pg} / \mathrm{ml}$, respectively,

Table 2. SOBI and PLI in different groups after treatment.

\begin{tabular}{|c|c|c|}
\hline Group & SOBI (points) & PLI (points) \\
\hline Control & $0.65 \pm 0.26$ & $2.43 \pm 0.63$ \\
\hline Model & $2.12 \pm 0.5^{5 *}$ & $4.08 \pm 0.84^{*}$ \\
\hline Low-dose AsIV & $1.98 \pm 0.48^{*}$ & $4.01 \pm 0.88^{*}$ \\
\hline Middle-dose AsIV & $1.47 \pm 0.41^{* * * * * * *}$ & $3.89 \pm 0.79^{*}$ \\
\hline High-dose AsIV & $1.12 \pm 0.33^{*,+*,+* *+* * * *}$ & $2.95 \pm 0.75^{* * * *+* *,+* * * *}$ \\
\hline
\end{tabular}

$p<0.05$ compared with the control group; " $p<0.05$ compared with the model group; ${ }^{* * *} p<0.05$ compared with the low-dose AsIV group; and ${ }^{* * * *} p<0.05$ compared with the middle-dose AsIV group. AsIV, astragaloside IV; SOBI, salivary occult blood index; and PLI, plaque index.
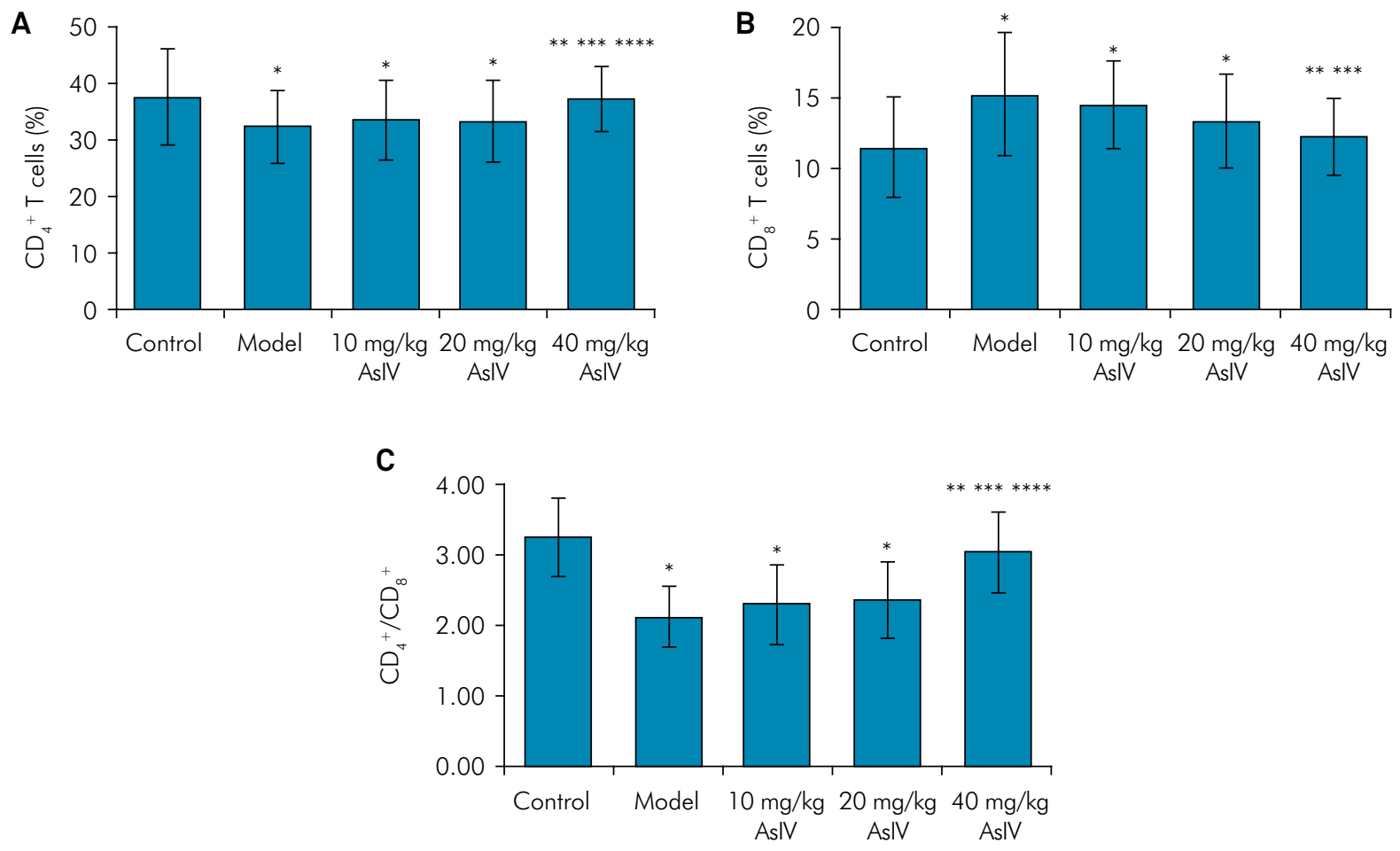

Figure 1. Peripheral blood T lymphocyte subsets in different groups after treatment. $A: C D_{4}^{+} ; B_{:}: C D_{8}^{+} ;$and $C: C D_{4}{ }^{+} / C D_{8}{ }^{+}$ratio. " $p<0.05$ compared with the control group; ${ }^{* *} p<0.05$ compared with the model group; ${ }^{* * *} \mathrm{p}<0.05$ compared with the $10 \mathrm{mg} / \mathrm{kg}$ AsIV group; and ${ }^{* * * *} \mathrm{p}<0.05$ compared with the $20 \mathrm{mg} / \mathrm{kg}$ AsIV group. AsIV, astragaloside IV. 
which were significantly higher than the levels in the control group, which were $3.62 \pm 0.84,179.67 \pm 39.56$ and $36.67 \pm 9.67 \mathrm{pg} / \mathrm{mlthe}$, respectively $(\mathrm{p}<0.05)$. In the $40 \mathrm{mg} / \mathrm{kg}$ AsIV group, the serum TNF- $\alpha$, IL-1 $\beta$ and IL-2 levels were $3.72 \pm 0.75,187.12 \pm 58.17$ and $33.12 \pm 7.65 \mathrm{pg} / \mathrm{ml}$, respectively, and these levels were significantly lower than those in the model group $(\mathrm{p}<0.05)$ (Figure 2).

\section{Serum IgA, IgG and IgM levels after treatment}

After treatment, the serum IgA and IgG levels in the model group were $1.12 \pm 0.37$ and $4.33 \pm 0.92 \mathrm{mg} / \mathrm{ml}$, respectively, which were significantly higher than the levels of $0.36 \pm 0.05$ and $0.66 \pm 0.25 \mathrm{mg} / \mathrm{ml}$, respectively, in the control group ( $\mathrm{p}<0.05)$. In the $20 \mathrm{mg} / \mathrm{kg}$ AsIV group, the serum IgA and IgG levels were $0.83 \pm 0.45$ and $1.55 \pm 0.54 \mathrm{mg} / \mathrm{ml}$, respectively. In the $40 \mathrm{mg} / \mathrm{kg}$ AsIV group, the serum IgA and IgG levels were $0.61 \pm 0.34$ and $1.19 \pm 0.24 \mathrm{mg} / \mathrm{ml}$, respectively. Each index in the 20 and $40 \mathrm{mg} / \mathrm{kg}$ AsIV groups was significantly lower than the corresponding index in the model group $(\mathrm{p}<0.05)$. There was no significant difference in the serum IgM levels among the five groups $(\mathrm{p}>0.05)$ (Figure 3$)$.

\section{Discussion}

This study investigated the effects of AsIV on inflammation and immunity in rats with experimental periodontitis. The results indicate that AsIV can mitigate periodontitis in rats. Tlymphocyte subsets are important indicators of cellular immune function. $\mathrm{CD}_{4}{ }^{+}$ and $\mathrm{CD}_{8}{ }^{+} \mathrm{T}$ cells are two kinds of important immune regulatory cells in the immune system and are the central links that determine the stability of the internal immune environment. Under normal circumstances, the ratio of $\mathrm{CD}_{4}^{+} / \mathrm{CD}_{8}{ }^{+}$remains stable. ${ }^{16,17}$ Studies have shown that the ratio of $\mathrm{CD}_{4}{ }^{+} / \mathrm{CD}_{8}{ }^{+}$in the peripheral blood of animals or patients with periodontitis is
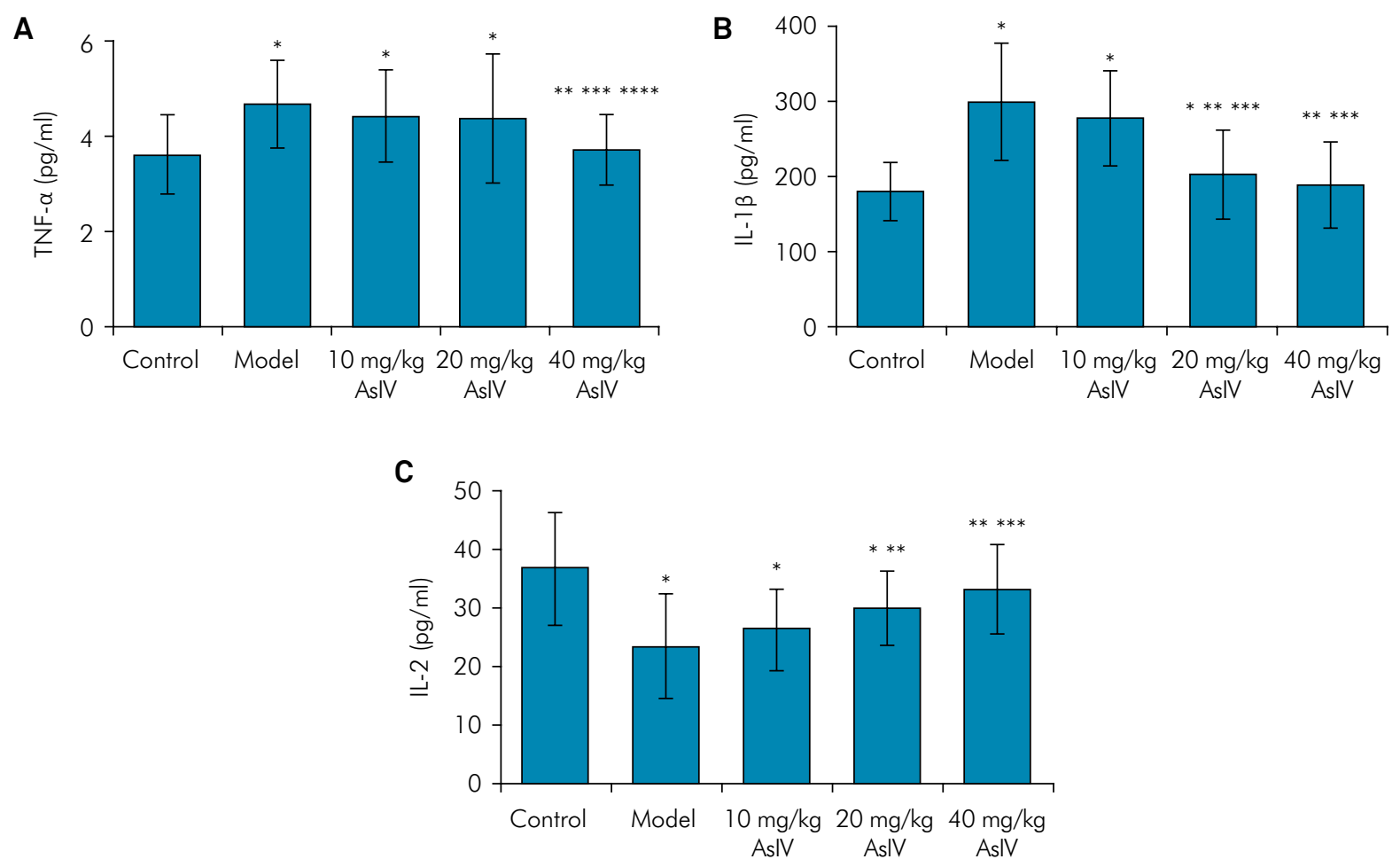

Figure 2. Serum TNF- $\alpha, I L-1 \beta$ and IL-2 levels in different groups after treatment. A: TNF- $\alpha$; B: IL-1 $\beta$; and C: IL-2. ${ }^{*} p<0.05$ compared with the control group; ${ }^{* *} p<0.05$ compared with the model group; ${ }^{* * *} \mathrm{p}<0.05$ compared with the $10 \mathrm{mg} / \mathrm{kg}$ AsIV group; and ${ }^{* * * *} \mathrm{p}<0.05$ compared with the $20 \mathrm{mg} / \mathrm{kg}$ AsIV group. AsIV, astragaloside IV; TNF- $\alpha$, tumor necrosis factor- $\alpha$; IL-1 $\beta$, interleukin-1 $\beta$; and IL-2, interleukin-2. 
A

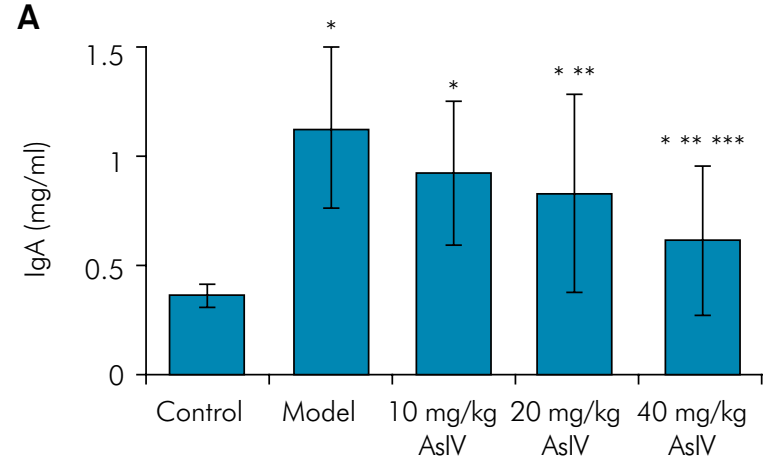

B

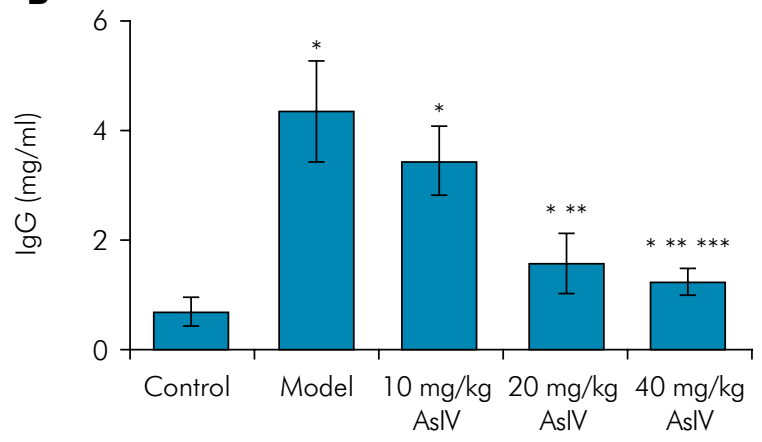

Figure 3. Serum $\lg A$, $\lg G$ and $\lg M$ levels in different groups after treatment. A: $\lg A$; $B$ : $\lg G$; and C: $\lg M$. " $p<0.05$ compared with the control group; ${ }^{* *} p<0.05$ compared with the model group; and ${ }^{* * *} p<0.05$ compared with the $10 \mathrm{mg} / \mathrm{kg}$ AsIV group. AsIV, astragaloside IV; lgA, immunoglobulin $A$; lgG, immunoglobulin $G$; and lg $M$, immunoglobulin $M$.

significantly reduced..$^{18}$ In this study, after treatment, the $\mathrm{CD}_{4}{ }^{+} \mathrm{T}$ cell percentage and $\mathrm{CD}_{4}{ }^{+} / \mathrm{CD}_{8}{ }^{+}$ratio in the model group were significantly lower than those in the control group, and the $\mathrm{CD}_{8}{ }^{+} \mathrm{T}$ cell percentage in the model group was significantly higher than that in the control group. Compared with the model group, the $40 \mathrm{mg} / \mathrm{kg}$ AsIV group exhibited significant increases in the $\mathrm{CD}_{4}{ }^{+} \mathrm{T}$ cell percentage and $\mathrm{CD}_{4}{ }^{+} / \mathrm{CD}_{8}{ }^{+}$ ratio and a significant decrease in the $\mathrm{CD}_{8}{ }^{+} \mathrm{T}$ cell percentage. These findings indicate that AsIV can improve the distribution of T lymphocyte subsets in the peripheral blood.

The occurrence of periodontal disease involves a series of immune responses. ${ }^{19}$ IL-1 is a cytokine produced mainly by monocytes/ macrophages. There are two types of IL- 1 ( $\alpha$ and $\beta 2$ ), and IL-1 $\beta$ plays a key role in the process of bone destruction in periodontitis. ${ }^{20}$ In animals with experimental periodontitis, blocking IL-1 receptors can significantly reduce the aggregation of inflammatory cells and formation of osteoclasts, which ultimately reduces the loss of alveolar bone. ${ }^{21} \mathrm{IL}-2$ is the major cytokine responsible for the proliferation of T cells. In addition to promoting the proliferation and activation of T cells, IL-2 can mediate the immune process in the body by inhibiting apoptosis in $\mathrm{T}$ cells, stimulating the growth of NK cells, enhancing the killing function of NK cells, and stimulating the growth of B cells and antibody production. ${ }^{22}$ TNF- $\alpha$ also plays an important role in periodontal tissue destruction. It can stimulate collagenase-mediated tissue destruction, induce osteoclast precursor cell proliferation and differentiation, and indirectly act on mature osteoclasts to stimulate bone resorption. ${ }^{23}$ In this study, compared with those in the model group, the serum TNF- $\alpha$, IL-1 $\beta$ and IL-2 levels in the $40 \mathrm{mg} / \mathrm{kg}$ AsIV group were significantly decreased. These observations indicate that AsIV can alleviate the inflammatory reaction in periodontitis rats.

Poor immune function can lead to infection, tumor formation or immunodeficiency-related diseases. Immunoglobulins are a group of proteins with antibody activities. They combine with antigens to eliminate pathogens and neutralize toxins. Immunoglobulins are an important part of the immune system, and their content, to a certain extent, reflects the strength of the body's immune function. ${ }^{24}$ A previous study showed that the serum IgA, IgG and IgM levels in patients with periodontitis are increased, especially in the early stage of disease. ${ }^{25}$ In this study, after treatment, the serum IgA and IgG levels in the 20 and $40 \mathrm{mg} / \mathrm{kg}$ AsIV groups were significantly lower than those in the model group. This result indicates that AsIV can alleviate immunological stress in periodontitis rats. However, there was no significant difference in the serum IgM levels among the five groups. The reason needs to be further investigated.

In conclusion, AsIV can alleviate inflammation and enhance immunity in rats with experimental periodontitis. This study has provided a theoretical basis for the clinical application of AsIV for the 
treatment of periodontitis. There are still limitations to this study. First, the correlations between inflammation and immunity indexes have not been investigated.
Second, there may be other mechanisms underlying how AsIV alleviates periodontitis in rats. These issues need to be addressed in further studies.

\section{References}

1. Heitz-Mayfield LJ, Schätzle M, Löe H, Bürgin W, Anerud A, Boysen H, et al. Clinical course of chronic periodontitis. II. Incidence, characteristics and time of occurrence of the initial periodontal lesion. J Clin Periodontol. 2003 Oct;30(10):902-8. https://doi.org/10.1034/i.1600-051X.2003.00399.x

2. Amano A. Bacterial adhesins to host components in periodontitis. Periodontol 2000. 2010 Feb;52(1):12-37. https://doi.org/10.1111/j.1600-0757.2009.00307.x

3. Scarel-Caminaga RM, Trevilatto PC, Souza AP, Brito RB, Line SR. Investigation of an IL-2 polymorphism in patients with different levels of chronic periodontitis. J Clin Periodontol. 2002 Jul;29(7):587-91. https://doi.org/10.1034/j.1600-051X.2002.290701.x

4. Jiang ZL, Cui YQ, Gao R, Li Y, Fu ZC, Zhang B, et al. Study of TNF- $\alpha, I L-1 \beta$ and LPS levels in the gingival crevicular fluid of a rat model of diabetes mellitus and periodontitis. Dis Markers. 2013;34(5):295-304. https://doi.org/10.1155/2013/156798

5. Hu Z, Zhang Y, Li Z, Yu Y, Kang W, Han Y, et al. Effect of Helicobacter pylori infection on chronic periodontitis by the change of microecology and inflammation. Oncotarget. 2016 Oct;7(41):66700-12. https://doi.org/10.18632/oncotarget.11449

6. Sanz M, Bäumer A, Buduneli N, Dommisch H, Farina R, Kononen E, et al. Effect of professional mechanical plaque removal on secondary prevention of periodontitis and the complications of gingival and periodontal preventive measures: consensus report of group 4 of the 11th European Workshop on Periodontology on effective prevention of periodontal and peri-implant diseases. J Clin Periodontol. 2015 Apr;42 Suppl 16:S214-20. https://doi.org/10.1111/jcpe.12367

7. Kaner D, Christan C, Dietrich T, Bernimoulin JP, Kleber BM, Friedmann A. Timing affects the clinical outcome of adjunctive systemic antibiotic therapy for generalized aggressive periodontitis. J Periodontol. 2007 Jul;78(7):1201-8. https://doi.org/10.1902/jop.2007.060437

8. Huang LF, Yao YM, Li JF, Zhang SW, Li WX, Dong N, et al. The effect of Astragaloside IV on immune function of regulatory $T$ cell mediated by high mobility group box 1 protein in vitro. Fitoterapia. 2012 Dec;83(8):1514-22. https://doi.org/10.1016/j.fitote.2012.08.019

9. Zhang WJ, Hufnagl P, Binder BR, Wojta J. Antiinflammatory activity of astragaloside IV is mediated by inhibition of NF-kappaB activation and adhesion molecule expression. Thromb Haemost. 2003 Nov;90(5):904-14. https://doi.org/10.1160/TH03-03-0136

10. Wang S, Li J, Huang H, Gao W, Zhuang C, Li B, et al. Anti-hepatitis B virus activities of astragaloside IV isolated from radix Astragali. Biol Pharm Bull. 2009 Jan;32(1):132-5. https://doi.org/10.1248/bpb.32.132

11. Xu W, Shao X, Tian L, Gu L, Zhang M, Wang Q, et al. Astragaloside IV ameliorates renal fibrosis via the inhibition of mitogen-activated protein kinases and antiapoptosis in vivo and in vitro. J Pharmacol Exp Ther. 2014 Sep;350(3):552-62. https://doi.org/10.1124/ipet.114.214205

12. Jiang $P, M a D$, Wang $X$, Wang $Y, B i$ Y, Yang J, et al. Astragaloside IV Prevents obesity-associated hypertension by improving proinflammatory reaction and leptin resistance. Mol Cells. 2018 Mar;41(3):244-55.

13. Li J, Zhong J, Cui L, Luo R. Therapeutic action and the discussion of immunologic mechanism for Wudansan gelatum treat the diabetes rat of merger of periodontitis [in Chinese]. China Modern Medicine. 2013 Jun;20(18):6-8.

14. Wood S, Metcalf D, Devine D, Robinson C. Erythrosine is a potential photosensitizer for the photodynamic therapy of oral plaque biofilms. J Antimicrob Chemother. 2006 Apr;57(4):680-4. https://doi.org/10.1093/jac/dkl021

15. Cortés-Barberena E, González-Márquez H, Gómez-Olivares JL, Ortiz-Muñiz R. Effects of moderate and severe malnutrition in rats on splenic T lymphocyte subsets and activation assessed by flow cytometry. Clin Exp Immunol. 2008 Jun;152(3):585-92. https://doi.org/10.1111/i.1365-2249.2008.03649.x

16. Chiou YL, Shih CJ, Ko WS. The increased ratio of CD4+/CD8+ was positively correlated with inflammation in hepatitis $C$ patients with metabolic syndrome. Clin Biochem. 2013 Jun;46(9):745-9. https://doi.org/10.1016/i.clinbiochem.2013.03.016

17. Diederichsen AC, Hjelmborg J, Christensen PB, Zeuthen J, Fenger C. Prognostic value of the CD4+/CD8+ ratio of tumour infiltrating lymphocytes in colorectal cancer and HLA-DR expression on tumour cells. Cancer Immunol Immunother. 2003 Jul;52(7):423-8. https://doi.org/10.1007/s00262-003-0388-5

18. Nagasawa T, Nitta H, Watanabe H, Ishikawa I. Reduced CD8+ peripheral blood T lymphocytes in rapidly progressive periodontitis. Arch Oral Biol. 1995 Jul;40(7):605-8. https://doi.org/10.1016/0003-9969(95)00025-K 
Effects of astragaloside IV on inflammation and immunity in rats with experimental periodontitis

19. Ebersole JL, Novak MJ, Michalowicz BS, Hodges JS, Steffen MJ, Ferguson JE, et al. Systemic immune responses in pregnancy and periodontitis: relationship to pregnancy outcomes in the Obstetrics and Periodontal Therapy (OPT) study. J Periodontol. 2009 Jun;80(6):953-60. https://doi.org/10.1902/jop.2009.080464

20. Mark LL, Haffajee AD, Socransky SS, Kent RL Jr, Guerrero D, Kornman K, et al. Effect of the interleukin-1 genotype on monocyte IL-1 beta expression in subjects with adult periodontitis. J Periodontal Res. 2000 Jun;35(3):172-7. https://doi.org/10.1034/i.1600-0765.2000.035003172.x

21. Izawa A, Ishihara Y, Mizutani H, Kobayashi S, Goto H, Okabe E, et al. Inflammatory bone loss in experimental periodontitis induced by Aggregatibacter actinomycetemcomitans in interleukin-1 receptor antagonist knockout mice. Infect Immun. 2014 May;82(5):1904-13. https://doi.org/10.1128/IAI.01618-13

22. Cho HW, Kim SY, Sohn DH, Lee MJ, Park MY, Sohn HJ, et al. Triple costimulation via CD80, 4-1BB, and CD83 ligand elicits the longterm growth of $\mathrm{V} \gamma 9 \mathrm{~V} \delta 2 \mathrm{~T}$ cells in low levels of IL-2. J Leukoc Biol. 2016 Apr;99(4):521-9. https://doi.org/10.1189/jlb.1HI0814-409RR

23. Brandelero S Jr, Bonfleur ML, Ribeiro RA, Vanzela EC, Nassar CA, Nassar PO, et al. Decreased TNF- $\alpha$ gene expression in periodontal ligature in MSG-obese rats: a possible protective effect of hypothalamic obesity against periodontal disease? Arch Oral Biol. 2012 Mar;57(3):300-6. https://doi.org/10.1016/j.archoralbio.2011.08.024

24. Cannon JP, Dishaw LJ, Haire RN, Litman RT, Ostrov DA, Litman GW. Recognition of additional roles for immunoglobulin domains in immune function. Semin Immunol. 2010 Feb;22(1):17-24. https://doi.org/10.1016/i.smim.2009.11.006

25. Albandar JM, DeNardin AM, Adesanya MR, Winn DM, Diehl SR. Associations of serum concentrations of $\lg G, \lg A, \lg M$ and interleukin-1 beta with early-onset periodontitis classification and race. J Clin Periodontol. 2002 May;29(5):421-6. https://doi.org/10.1034/j.1600-051X.2002.290506.x 